\title{
Growth Performance and Nutrient Utilization of African Catfish (Clarias gariepinus) Juveniles Fed Varying Inclusions of Defatted African Palm Weevils (Rhynchophorus phoenicis) Meal
}

\author{
Ayodeji Benjamin Agbanimu ${ }^{1, *}\left(\mathbb{D}\right.$, Eunice Olwayemisi Adeparusi ${ }^{1}$
}

${ }^{1}$ Federal University of Technology, P.M.B. 704, Akure, Ondo State, Nigeria

\section{Article History \\ Received 23 Jun 2020 \\ Accepted 20 July 2020 \\ First Online 27 July 2020 \\ Corresponding Author \\ Tel.: +2347064393310 \\ E-mail: agbanimuaydeji2010@gmail.com}

\section{Keywords}

Defatted

Rhynchophorus phoenicis

Clarias gariepinus

Fish meal

\begin{abstract}
A feeding trial was conducted to examine the dietary effects of using African Palm weevil in the diet of Catfish. Five experimental diets containing $40 \%$ crude protein were formulated, four of these diets contained defatted African palm weevil larvae meal at varying inclusion levels denoted as APW25\%, APW50\%, APW75\% and APW100\% while the diet with fish meal (APW0\%) served as control diet. The experiment was conducted in triplicates for 10 weeks using 15 aquaria glass tanks with 10 fish per tank. The percentage weight gain was significantly different $(P>0.05)$ across the fish fed experimental diets, with the highest percentage weight gain (1118.30g) recorded in fish fed diet APW100 and the lowest percentage weight gain (749.40g) recorded in fish fed diet FM. The feed conversion ratio (FCR) were not significantly different $(P<0.05)$ across the experimental diet. The highest FCR value $(1.48 \pm 0.42)$ was recorded in the fish fed diet FM while the lowest FCR value $(1.06 \pm 0.01)$ was recorded in fish fed diet APW100. There were no significant differences $(P>0.05)$ in the PER among the experimental diets. It could be concluded that defatted African palm weevil larvae meal in the diet in replacement of fishmeal.in the diet Clarias gariepinus juvenile.
\end{abstract}

\section{Introduction}

The growth of aquaculture depends on the availability of good quality and relatively inexpensive feed ingredients for the formulation of fish diet, supplemental feed brings greater yields in ponds than if the fish were left to depends on natural (aquatic) food, various feeds are used in culturing fishes to enhance adequate fish growth, reproduction and survival (Miles and Chapman, 2006).

The source of fish feed, such as fishmeal are very expensive especially imported ones because of high rate of foreign exchange, while aquaculture's share of fish meal and fish oil consumption has been increased reaching $88 \%$ by 2007 as reported by Tacon and Metian, (2008). Fishmeal which serves as the main protein source for fish feed because of its high quality protein content, is not only expensive but also usually unavailable Tacon and Barg (1998), particularly in developing countries. Fagbenro and Davies (2003) and Ogunji et al, (2003) reported that efforts have been made to replace fishmeal with vegetable protein from other sustainable sources by many researchers. The production of fish meal decreased between 1994 and 2012 and is now about 5 to 6 million tonnes (Médale et al., 2013) and (FAO, 2014). As a consequence, there has been an ongoing search for alternative sources of protein that would allow aquaculture to remain economically and environmentally sustainable (Barroso et al., 2014).

Approximately 1,900 insect species are eaten worldwide, mainly in developing countries (Arnold, 2013). They constitute quality food and feed, Furthermore, in the recent years, insects have received 
wide attention as a potential source of protein both for humans and livestock. Research have shown current status on the insects that are the best candidates as fish feed ingredients in partial or complete substitution for fish meal, with regard to their nutritional attributes, ease of rearing, and biomass production. According to Riddick et al, (2013) larvae or pupae of Diptera black soldier fly (Hermetia illucens) and house fly (Musca domestica), larvae of mealworm Tenebrio molitor (Coleoptera), adult Orthoptera and pupae of silkworm Bombyx mori (Lepidoptera) has been used as replacement for fishmeal, and the results were positive.

The larva of the African palm weevils (Rhynchophorus phoenicis) popularly known as "Edible worm" is a delicacy in many parts of Nigeria and other countries in Africa where it is found (Ekpo, 2003). Several researches have been done on the nutritional composition of African palm weevils Rynchophorus phoenicis with a protein content of $(66.09 \% \mathrm{CP})$ as reported by Elemo et al, (2011), as well as the antinutritional factor which gives information on the usefulness of $R$. phoenicis in the animal and fish feeds as an alternative protein source (Ekpo, 2003). To the knowledge of this researcher no work has been done on the incorporation of this useful insect in animal or fish feeds. This research is therefore, aimed at evaluating for the first time, the substitution of fish meal with African palm weevil larvae meal, in catfish diets. It is believed that this study would provide the springboard on the usefulness of African palm weevil meal in the diet of Clarias gariepinus juvenile, and thus provide an inexpensive animal protein source for aquafeeds.

\section{Materials and Method}

The experiment was carried out at the Teaching and Research Farm of the Department of Fisheries and Aquaculture Technology, Federal University of Technology, Akure, Ondo State, Nigeria.

\section{Sample Collection}

Samples of $R$. phoenicis were obtained from the wild, the larvae were cleaned thoroughly with water and transported to the laboratory in a well-ventilated plastic container and was oven dried at $80^{\circ} \mathrm{C}$ for $24 \mathrm{hrs}$ as recommended by Banjo et al. (2006). The larvae were defatted (i.e. the fat content was extracted) by the method of (Bligh and Dyer, 1959). Proximate analysis of the defatted sample was done according to the method described by (AOAC, 2010).

\section{Preparation of Experimental Diets}

Five iso-nitrogenous diets were formulated to contain $40 \%$ crude protein with varying proportions at 0\% (Control), 25\% (APW), 50\% (APW), 75\% (APW), and $100 \%$ (APW) inclusion level of defatted $R$. phoenicis meal using trial and error method. The feed components include yellow maize, fish meal, soya beans, wheat offal, iodized salt, vegetable oil and vitamin premix trial (Table 1). Each of the feed ingredients was weighed and poured on a plastic container which was thoroughly mixed together thereafter boiled water. The dough was pelleted using a Horbart A-200T mixing and pelleting machine. The pellets were of $2 \mathrm{~mm}$ in diameter. The pelleted diets were sun-dried on raised platform.

\section{Feeding Trial}

This was conducted in 15 aerated glass tanks $(0.3 \times 05 x$. Juvenile from the same brood stocks were weighted and stocked randomly at ten (10) juvenile per tank in 60 litres of domestic water within the fish farm of the Department of Fisheries and Aquaculture Technology, Federal University of Technology, Akure, Ondo State, Nigeria. The juveniles were fed experimental diets twice daily at $5 \%$ body weight between $8.00-9.00$ hours and $16.00-17.00$ hours

Table 1. Gross Composition of Experimental Diet (g/100g)

\begin{tabular}{|c|c|c|c|c|c|}
\hline Ingredient & APWO & APW25 & APW50 & APW75 & APW100 \\
\hline Fishmeal (65\%CP) & 35 & 26.25 & 17.50 & 8.75 & - \\
\hline $\begin{array}{l}\text { R. phoenicis } \\
(66 \% \mathrm{CP})\end{array}$ & - & 8.62 & 17.23 & 25.85 & 34.46 \\
\hline Soybean meal(48\%CP) & 30 & 30 & 30 & 30 & 30 \\
\hline Fish oil & 1 & 1 & 1 & 1 & 1 \\
\hline Maize & 24 & 24.13 & 24.27 & 24.40 & 24.54 \\
\hline Salt & 2 & 2 & 2 & 2 & 2 \\
\hline Starch & 5 & 5 & 5 & 5 & 5 \\
\hline Premix & 3 & 3 & 3 & 3 & 3 \\
\hline Total & 100 & 100 & 100 & 100 & 100 \\
\hline Cost / (1kg) & 682.1 & 611.74 & 541.35 & 471 & 399.94 \\
\hline Estimated Crude Protein (\%) & 39.05 & 39.05 & 39.05 & 39.05 & 39.05 \\
\hline \multicolumn{6}{|l|}{ Proximate Composition(\%) } \\
\hline Moisture & 4.2 & 4.2 & 5.5 & 8.5 & 6.3 \\
\hline Ash & 20.38 & 18.6 & 18.6 & 15 & 14.8 \\
\hline Crude Protein & 39.75 & 41.40 & 41.65 & 42.88 & 43.75 \\
\hline Crude Fibre & 0.82 & 1.23 & 1.63 & 1.60 & 1.95 \\
\hline Lipid & 8.0 & 8.6 & 8.6 & 8.3 & 8.6 \\
\hline NFE & 26.85 & 25.75 & 24.02 & 23.72 & 24.60 \\
\hline
\end{tabular}


throughout the study period of 70 days. Feeding was monitored for each unit to ensure that fishes were not underfed or overfed. Experimental units were cleaned daily while changing of total water was done twice a week. Weekly weight gain and feed intake was recorded fortnightly. An electronic table top weigh balance (Metler, PB8001 UK) was used in weighing the fish and feed. The data on weight gain; feed conversion ratio and survival rates for the dietary. Water quality parameters of the experiment varied as follows: temperature, $\mathrm{pH}$, dissolved oxygen and conductivity of the culture water used for the 15 treatments. Temperature was $28.05^{\circ} \mathrm{C}$ to $28.45^{\circ} \mathrm{C}$, pH 6.60 to 6.75 , dissolved oxygen 5.4 to $5.9 \mathrm{mg} / \mathrm{l}$ and conductivity was 270.5 to $329.5 \mathrm{~s} / \mathrm{m}$.

Growth Parameters were assesed by using the following formula

Mean Weight Gain =Final Weight Gain - Initial Weight Gain

Specific growth rate $=\underline{\log _{\mathrm{e}} \mathrm{W} 2-\log _{\mathrm{e}} \mathrm{W} 1} \times 100$

Where

$W_{2}=$ Final Body Weight

$W_{1}=$ Initial Body Weight of fish

$\mathrm{T}=$ Duration of study in days

$$
\text { Daily Growth Rate }=\frac{\text { fish weight gain }}{\text { number of culture days }}
$$

Feed Conversion Ratio (FCR) $=\frac{\text { total dry feed intake by } f \text { ish }(g)}{\text { wet weight gain by } f \text { ish }(g)}$

$$
\text { Survival rate }(\mathrm{SR})=\frac{N 1-N 0}{N 1} \times 100
$$

Where

$\mathrm{N}_{0}=$ number of fish stocked

$\mathrm{N}_{1}=$ number of fish at the end of experiment

Protein Gain = Final Carcass weight - Initial Carcass weight

$$
\begin{gathered}
\text { Protein Fed }=\frac{\% C P \text { Feed } x \text { Feed Intake }}{100} \\
\text { Protein Efficiency Ratio }=\frac{\text { Fish weight gain }}{\text { protein fed }}
\end{gathered}
$$

Apparent Net Protein Utilization $=\frac{\text { Net protein gain }}{\text { protein } \text { fed }} \times 100$

Proximate analysis of diets and experimental fish was done using the methods described by AOAC (2010). Data were analysed by oneway ANOVA (Analysis of Variance) using Statistical Package for Social Sciences (SPSS v.21). Means were separated using New Duncan Multiple Range Test (DMRT).

\section{Results}

\section{Proximate Composition of Defatted African Palm Weevil Larvae Meal (Rhynchophorus phoenicis) and Fishmeal}

The result of the proximate composition of defatted African palm weevil larvae meal
(Rhynchophorus phoenicis) and fishmeal is presented in Table 2. The proximate composition of defatted African Palm Weevil larvae compares favourably with the fish meal used in this experiment. The crude protein content of African palm weevil was $65.58 \%$ as compared to $64.86 \%$ for fish meal.

\section{Growth Performance and Nutrient Utilization}

The growth performance and nutrient utilization of African Mud Catfish fed experiment diets is presented in Table 3. There was significant difference in the final mean weight (FWG), mean weight gain (MWG), daily growth rate (DGR), and specific growth rate (SGR). The final weight gain increases as the inclusion level of APW increases. There was no significant difference $(P<0.05)$ in the Feed conversion ratio (FCR), Protein intake, Protein Efficiency ratio (PER) and Survival across the treatments. Fish fed diet APW100 had the highest MWG, DGR, SGR, Protein Intake, PER and the lowest FCR. Fish fed diet APWO had the lowest MWG, DGR, SGR, Protein Intake, PER and the highest FCR.

The mean weight gain recorded in this study ranged from $41.76 \pm 6.22$ in APWO to $62.23 \pm 2.36 \mathrm{~g}$ in APW100. Fish fed diet APW100 recorded the highest Specific Growth Rate (SGR) value of $1.55 \pm 0.03$ and the lowest of $1.31 \pm 0.08$ in fish fed diet APWO. The fish fed diet APWO recorded the highest feed conversion ratio (FCR) value of $1.48 \pm 0.42$ and the lowest value is recorded in fish fed diet APW100 of $1.06 \pm 0.01$. The protein efficiency ratio (PER) ranged from $1.75 \pm 0.3$ to 2.31 \pm 0.02 , which was highest in fish fed diet APW75 and lowest in fish fed diet FM. The result obtained for PER shows that there were no significant differences ( $P>0.05$ ) among the diets. The percentage survival in all the fish fed experimental diets were not significantly different $(P>0.05)$ from each other. The fish fed diet APWO had the lowest percentage survival value of $76.66 \%$ and fish fed diet APW75 and APW100 had the highest value of $96.66 \%$ and $96.66 \%$ respectively.

\section{Carcass Composition of African Mud Catfish Clarias gariepinus Juvenile Fed Experimental Diet for $\mathbf{7 0}$ days}

Result of carcass composition of experimental fish fed experimental diets is presented in Table 4. Crude protein content of carcass of fish fed varying inclusion level of APW was significantly different $(P<0.05)$. The highest crude protein was obtained in fish fed diet APW100 $(62.86 \pm 0.02 \%)$ while control diet had the lowest crude protein $(60.22 \pm 0.06 \%)$. The crude protein content of initial fish was significantly higher than those of experimental fish at the end of the experiment. There was significant difference $(P<0.05)$ in the ash content of experimental fish. The ash content was highest in diet APW100 (14.60 $\pm 0.00 \%)$ and least in diet APW25 $(12.33 \pm 0.57 \%)$. The highest fat content was obtained in fish fed diet APW25 (18.00 $\pm 0.00 \%)$ while the least was 
Table 2. Proximate Composition of Defatted African Palm Weevil Larvae Meal (Rhynchophorus phoenicis) and Fishmeal

\begin{tabular}{lcc}
\hline \multirow{2}{*}{ Components } & \multicolumn{2}{c}{ Mean value } \\
\cline { 2 - 3 } & APW \% & FM \% \\
\hline Moisture & 9.00 & 8.60 \\
Ash & 12.00 & 14.00 \\
Lipid & 4.00 & 9.00 \\
Protein & 65.58 & 64.86 \\
Fibre & 1.49 & 0.07 \\
\hline
\end{tabular}

Table 3. Growth Performance and Nutrient Utilization of African Mud Catfish Clarias gariepinus Juveniles Fed Experimental diets for 70days

\begin{tabular}{|c|c|c|c|c|c|}
\hline Parameters & APWO & APW 25 & APW 50 & APW 75 & APW 100 \\
\hline $\begin{array}{l}\text { Initial Mean } \\
\text { weight }\end{array}$ & $5.57 \pm 0.00^{\mathrm{a}}$ & $5.56 \pm 0.01^{\mathrm{a}}$ & $5.48 \pm 0.01^{\mathrm{a}}$ & $5.57 \pm 0.00^{a}$ & $5.56 \pm 0.01^{a}$ \\
\hline $\begin{array}{l}\text { Final } \\
\text { Mean Weight }\end{array}$ & $47.33 \pm 6.22^{\mathrm{a}}$ & $50.27 \pm 0.87^{a}$ & $63.20 \pm 2.35^{b}$ & $63.34 \pm 0.78^{b}$ & $67.79 \pm 2.37^{b}$ \\
\hline $\begin{array}{l}\text { Mean weight } \\
\text { gain }\end{array}$ & $41.76 \pm 6.22^{\mathrm{a}}$ & $44.71 \pm 0.88^{a}$ & $57.72 \pm 2.45^{b}$ & $57.77 \pm 0.77^{b}$ & $62.23 \pm 2.36^{b}$ \\
\hline $\begin{array}{l}\text { Daily growth } \\
\text { rate }\end{array}$ & $0.59 \pm 0.08^{a}$ & $0.63 \pm 0.01^{\mathrm{a}}$ & $0.82 \pm 0.03^{b}$ & $0.82 \pm 0.01^{b}$ & $0.88 \pm 0.03^{b}$ \\
\hline $\begin{array}{l}\text { Specific growth } \\
\text { rate }\end{array}$ & $1.31 \pm 0.08^{a}$ & $1.36 \pm 0.01^{\mathrm{a}}$ & $1.51 \pm 0.03^{b}$ & $1.50 \pm 0.01^{b}$ & $1.55 \pm 0.03^{b}$ \\
\hline $\begin{array}{l}\text { Total feed } \\
\text { intake }\end{array}$ & $61.76 \pm 5.29^{a}$ & $57.46 \pm 3.89^{a}$ & $64.55 \pm 4.00^{\mathrm{a}}$ & $62.54 \pm 1.54^{a}$ & $66.42 \pm 2.37^{a}$ \\
\hline FCR & $1.48 \pm 0.42^{\mathrm{a}}$ & $1.28 \pm 0.06^{a}$ & $1.11 \pm 0.02^{\mathrm{a}}$ & $1.08 \pm 0.01^{\mathrm{a}}$ & $1.06 \pm 0.0^{\mathrm{a}}$ \\
\hline Protein intake & $24.70 \pm 2.11^{\mathrm{a}}$ & $22.98 \pm 1.55^{a}$ & $25.82 \pm 1.60^{a}$ & $25.01 \pm 0.61^{\mathrm{a}}$ & $27.361 \pm 0.94^{a}$ \\
\hline PER & $1.75 \pm 0.36^{\mathrm{a}}$ & $1.95 \pm 0.10^{\mathrm{a}}$ & $2.24 \pm 0.04^{\mathrm{a}}$ & $2.31 \pm 0.02^{\mathrm{a}}$ & $2.27 \pm 0.04^{\mathrm{a}}$ \\
\hline Nitrogen & 789.26 & 845.02 & $1091.00 \pm 46.31^{b}$ & $1091.00 \pm 14.71^{b}$ & $1176.10 \pm 44.64^{b}$ \\
\hline Metabolism & $\pm 11.56^{\mathrm{a}}$ & $\pm 16.75^{\mathrm{a}}$ & & & \\
\hline \%Survival & $92.66 \pm 8.81^{a}$ & $90.00 \pm 5.77^{a}$ & $93.33 \pm 6.66^{a}$ & $96.66 \pm 3.33^{\mathrm{a}}$ & $96.66 \pm 3.33^{a}$ \\
\hline
\end{tabular}

Means on the same row with different superscripts are significantly different $(\mathrm{P}<0.05)$

Table 4. Carcass Composition of African Mud Catfish Clarias gariepinus Juveniles Fed Experimental Diet for 70days

\begin{tabular}{lcccccc}
\hline Parameter & Initial & APW0 & APW 25 & APW 50 & APW 75 & APW 100 \\
\hline Moisture & $6.00 \pm 0.01^{\mathrm{e}}$ & $4.60 \pm 0.05^{\mathrm{a}}$ & $4.71 \pm 0.15^{\mathrm{b}}$ & $4.90 \pm 0.05^{\mathrm{c}}$ & $5.00 \pm 0.15^{\mathrm{d}}$ & $4.60 \pm 0.00^{\mathrm{a}}$ \\
Ash & $12.14 \pm 0.22^{\mathrm{a}}$ & $14.33 \pm 0.57^{\mathrm{b}}$ & $12.33 \pm 0.57^{\mathrm{a}}$ & $14.00 \pm 0.00^{\mathrm{b}}$ & $12.80 \pm 0.17^{\mathrm{a}}$ & $14.60 \pm 0.00^{\mathrm{b}}$ \\
Crude Protein & $64.50 \pm 0.00^{\mathrm{f}}$ & $60.22 \pm 0.06^{\mathrm{a}}$ & $62.62 \pm 0.05^{\mathrm{d}}$ & $62.40 \pm 0.05^{\mathrm{b}}$ & $62.51 \pm 0.01^{\mathrm{c}}$ & $62.86 \pm 0.02^{\mathrm{e}}$ \\
Fat & $9.00 \pm 0.00^{\mathrm{a}}$ & $14.00 \pm 0.00^{\mathrm{b}}$ & $18.00 \pm 0.00^{\mathrm{c}}$ & $14.00 \pm 0.00^{\mathrm{b}}$ & $17.66 \pm 0.51^{\mathrm{c}}$ & $14.00 \pm 0.00^{\mathrm{b}}$ \\
Crude fibre & $0.07 \pm 0.00^{\mathrm{a}}$ & $0.06 \pm 0.00^{\mathrm{a}}$ & $0.07 \pm 0.01^{\mathrm{a}}$ & $0.07 \pm 0.36^{\mathrm{a}}$ & $0.08 \pm 0.00^{\mathrm{a}}$ & $0.08 \pm 0.00^{\mathrm{a}}$ \\
NFE & $8.29 \pm 0.00^{\mathrm{d}}$ & $6.79 \pm 0.06^{\mathrm{c}}$ & $2.27 \pm 0.57^{\mathrm{a}}$ & $4.63 \pm 0.01^{\mathrm{b}}$ & $1.95 \pm 0.05^{\mathrm{a}}$ & $3.86 \pm 2.82^{\mathrm{b}}$
\end{tabular}

Values are presented as mean $\pm \mathrm{SD}$; values with similar superscripts on the same row are not significantly different $(\mathrm{P}>0.05)$

in fish fed diet APW0, APW50 and APW100 $(14.00 \pm 0.00 \%)$. There was significant difference in the NFE content of experimental fish.

\section{Discussion}

The result of this study showed an increase in the body weight of the experimental fish. The experiment showed that there was a general increase in weight gain in all the treatment which indicates that the experimental fish were able to convert feed protein to flesh or body tissue. It was observed from the study that the mean weight gain of the fish showed that fish fed diet APW50, APW75 and APW100 had no significant difference $(P>0.05)$ with the value of 57.72g, 57.77g and $62.23 \mathrm{~g}$ respectively. The superiority shown could be attributed to the high protein content of the insect. The findings from this study also agree very closely with those of Ajonina and Nyambi (2013), who observed the best growth performance of Clarias gariepinus fingerlings, fed experimental diets containing dried maggot meal over those solely fed on fish meal diet. Fasakin et al., (2003) reported that fish performed better when fed diets containing defatted maggot meals than full-fat maggot meal, and compared favourably with fish fed the fish meal-based diet.

The non-significant differences $(P>0.05)$ of the evaluated growth and nutrient utilization indices among 
the five treatments imply that African palm weevil larvae meal can successfully replace the entire fishmeal portion of the fish diet. This study corroborates with the finding of Ogunji et al. (2006), who observed a better growth performance and nutrient utilization of Clarias gariepinus fed experimental diets containing maggot meal over those solely fed on fish meal diets. This is a reflection of the nutritive quality and acceptance of this biomaterial. These results are also in agreement with Alegbeleye et al., (1991) and Idowu et al., (2003) who reported that maggot meal, like other animal protein sources was well accepted and utilized by catfish Clarias gariepinus.

The non-significant difference $(P>0.05)$ in the values of FCR of fish fed experimental diet which ranged from $1.08 \pm 0.01$ to $1.48 \pm 0.42$ is possibly indicative that both protein sources compared favourably in feed to flesh conversion. It has been reported that the biological value of maggot meal is equivalent to that of whole fish meal (Ajani et al., 2004). This fact is further strengthened by the results obtained in this study. The PER values were good and not significantly different ( $P>0.05$ ) from control diet, which ranged between $1.75 \pm 0.36$ to $2.31 \pm 0.01$ and this corroborate with the results reported by Adebayo and Quadri (2005), that amino acid profile of maggot meal is similar to that of fish meal and meat meal, with a positive linear effect on the fish body protein of Heterobranchus bidorsallis.

The cost of producing a kilogram of African Palm Weevil larvae ranged from N399.94k - N611.74k is low when compared with Fish meal of N682.10k this indicate that using APW in replacement to Fish meal can reduce cost of production.

The proximate composition of the carcass of fish fed the experimental diets showed significant difference $(P<0.05)$, the crude protein values obtained for the fish fed experimental diet were significantly lower than the initial fish with a range of $60.22 \pm 0.06$ to $64.50 \pm 0.02$, the high in crude protein of the initial fish could be due to the foreign feed (skretting) given to fish before they were acquired for the experiment. The final fat content values of the fish on all the diet were significantly higher than the initial $(P<0.05)$ with a range of $9.00 \pm 0.00$ to $18.00 \pm 0.00$. This increase in lipid deposits in the carcass of fish fed experimental diet of defatted African palm weevil larvae meal could be due to fish oil used for the formulation of the experimental diet which may be responsible for the better growth in terms of weight rather than the crude protein. It has also been reported that defatted African palm weevil larvae meal is rich in essential amino acids necessary for growth and development as reported by FAO, (1991), Ekpo and Onigbinde, (2005).

The result obtained is in agreement with the finding of $\mathrm{Ng}$ et al., (2001) who reported that catfish fed dried mealworm-based diets had significantly more lipids in their carcass, and Makkar et al., (2014) reported similar result for channel catfish fed defatted black soldier fly larvae meal. This study reveals the possibility of utilizing defatted African palm weevil larvae meal in the diet of Clarias gariepinus juvenile.

\section{Conclusion}

This study shows that feeding African mud catfish, Clarias gariepinus juvenile with diets containing defatted African palm weevil, R. phoenicis meal gave better growth performance, carcass composition, and nutrient utilization. African Mud Catfish, Clarias gariepinus was able to utilize defatted African palm weevil meal as protein source better than fishmeal. The protein content of African palm weevil, $R$. phoenicis is enhanced if some level of defatting is done to further increase the protein component thus reducing overhead cost associated with fishmeal importation in developing countries like Nigeria.

\section{Acknowledgement}

The authors appreciate the Department of Fisheries and Aquaculture Technology, Federal University of Technology Akure, Nigeria for the use of their facility for the experiment

\section{References}

Adebayo, O.T. \& Quadri I.C. (2005). Dietary protein level and Feeding rate for Hybrid ClaridCatfish, Clarias gariepinus $\mathrm{x}$ Heterobranus bidorsallis in homestead tanks. Journal of Applied Aquaculture 17 (1): 97-106.

Ajani, E.K.; L.C. Nwanna \& B.O. Musa. (2004) Replacement of fishmeal with maggot meal in the diets of Nile tilapia, Oreochromis niloticus. World Aquaculture, 35 (1): 52-54.

Alegbeleye, W.O., Anyanwu, D.F. \& Akeem, A.M. (1991). Effect of varying dietary protein levels on the growth and utilization performance of catfish, Clarias gariepinus. Proceedings of the $4^{\text {th }}$ Annual Conference of Nigerian Association of Aquatic Science Ibadan, Nigeria. p 51-53.

AOAC (2010). Association of Official Analytical Chemists. Official Methods of Analysis. (15th ed.) Arlington, VA, USA.

Arnold, V.H. (2013). Potential of Insects as Food and Feed in Assuring Food Security. Annual Review Entomology. 58:563-83

Banjo, A.D., Lawa, O.A. \& Songonuga, E.A. (2006). The Nutritional Value of Fifteen Species of Edible Insects in Southwestern Nigeria. African Journal of Biotechnology, 5: 298- 301.

Barroso, F.G., de Haro, C.M., Sanchez-Muros, J., Venegas, E., Martinez-Sanchez, A. \& Perez-Bañon, C. (2014). The potential of various insect species for use as food for fish. Aquaculture, 422/423:193-201.

Bligh, E.G. \& Dyer, N. J. (1959). A rapid method for total lipid extraction and purification. Canadian Journal of Biochemistry and Physiology, 37: 911-917.

Ekpo, K. \& Onigbinde, A., (2005). Nutritional potentials of the larva of Rhynchophorus phoenicis (F). Pakistan Journal of Nutrition 4: 287-290.

Ekpo, K.E., (2003). Biochemical investigation of the nutritional value and toxicological safety of entomophagy in Sourthern Nigeria. Ph.D Thesis, Ambrose Alli University, 
Ekpoma, Edo State.

Elemo B, Elemo G, Makinde M, Erukainure O. (2011). Chemical evaluation of African palm weevil, Rhychophorus entomophagy in Sourthern Nigeria. Ph.D Thesis, Lagos State University, Lagos, Nigeria. Journal of Insect Science, 1536-2442 | Vol. 11, Number 146

Fagbenro, A.O. \& Davies, S.J. (2003). Use of high percentages of soy protein concentrate as fishmeal substitute in practical diets for African catfish, Clarias gariepinus (Burchell 1822) growth, feed utilisation and digestibility. Journal of Applied Aquaculture. 16(1).

FAO. (2014). The state of world fisheries and aquaculture 2014. FAO, Rome

FAO/WHO. (1991). Energy and protein requirements: Report of a joint FAO/WHO ad hoc expert committee. FAO Nutrition Meetings on Rhynchophorus phoenicis (F). Report Series No. 52. WHO Technical Report Series No. 522.

Fasakin, E.A., Balogun, A.M. \& Ajayi, O.O. (2003). Nutrition implication of processed maggot meals; hydrolyzed, defatted, full-fat, sun-dried and ovendried, in the diets of Clarias gariepinus fingerlings. Aquaculture Research 9 (34): 733-738.

Idowu, A.B., Amusan, A.A.S. \& Oyediran, A. G. (2003). The response of $C$. gariepinus (Burchell 1822) to the diet containing housefly maggot, (Musca domestica). Nigerian Journal of Animal Production 30 (1): 139-144.

Makkar, H.P.S., Tran, G., Heuzé, V. \& Ankers, P. (2014). Review: State-of-the-art on use of insects as animal feed. Animal Feed Science and Technology, 197:1-33.

Médale, F., Le Boucher, R., Dupont-Nivet, M., Quillet, E., Aubin, J., \& Panserat, S. (2013). Plant-based foods for farmed fish. INRAE Productions Animales, 26(4), 303-316. https://doi.org/10.20870/productionsanimales.2013.26.4.3159

Miles, R. \& Chapman, F. (2006). Benefits of fish meal in aquaculture diets. IFAS Extension, University of Florida.

Ng, W. K., Liew, F. L., Ang, L.P. \& Wong, K.W. (2001). Potential of mealworm (Tenebrio molitor) as an alternative protein source in practical diets for African catfish, Clarias gariepinus. Aquacult. Res., 32 (Supplement 1): 273-280

Ogunji, J.O.; Wirth, M.; Osuigwe, D.I. (2003). Nutrient composition of some tropical legumes capable of substituting fish meal in fish diets. Journal of Agriculture and Rural Devlopment in the Tropics and Subtropics (Der Tropenlandwirt), 104 (2): 143-148

Ogunji, J., Slawski, H., Schulz, C., Werner, C. \& Wirth, M. (2006). Preliminary evaluation of housefly maggot meal as an alternative protein source in diet of carp (Cyprinus carpio L.) World Aquaculture Society Abstract Data Aqua 2006 Meeting, Abstract 277.

Riddick. W. (2013). Insect protein as a partial replacement for fishmeal in the diets of juvenile fish and crustaceans: Invertebrates and entomopathogens. In: J.A. MoralesRamos, M.G. Rojas, and D.I. Shapiro-llan, editors, Mass production of beneficial organisms. Elsevier Science, Burlington, MA. p. 565-582.

Tacon, A.G.J. \& Barg, U.B. (1998). Major challenges to feed development for marine and diadromous finfish and crustacean species. In: Tropical Mariculture, De Silva, S.S. (ed.). Academic Press, London, pp. 171-207

Tacon, A.G.J. \& Metian, M. (2008). Global overview on the use of fish meal and fish oil in industrially compounded aquafeeds: Trends and future prospects. Aquaculture 285:146 158 